\title{
Complexity systems and middle-income trap: the long-term roots of Latin America underdevelopment
}

Sistemas complexos e armadilha da renda media: as raízes de longo prazo do subdesenvolvimento latino-americano

\author{
Fernanda Cimini ${ }^{(1)}$ \\ Jorge Britto (2) \\ Leonardo Costa Ribeiro (1) \\ (1) Universidade Federal de Minas Gerais \\ (2) Universidade Federal Fluminense
}

\begin{abstract}
Our intent is to reinterpret the concept of middle-income trap using the language of the complex system approach to refer to the unpredictability, non-linearity and the enormous range of possible behaviors of economic development in the long-term time series. By redefining the concept of trap in those terms, we propose to shed light on the institutional background of economic development. In order to advance our argument, we conduct a case study of Latin America, a region that has presented an unstable and non-linear economic trajectory across the 20 th century. We argue that the combination between the colonial economic legacy and the political fragmentation amid the process of independence shaped the socio-economic structure and institutional capabilities for years to come, restricting the possibilities of overcoming underdevelopment.
\end{abstract}

\section{Keywords}

middle-income trap, complex system, institutions, Latin America, underdevelopment.

JEL Codes 010, 014, O33, B15, C32.

\section{Resumo}

$O$ artigo busca reinterpretar o conceito de armadilha da renda média utilizando a linguagem de sistemas complexos para abordar a imprevisibilidade, a não linearidade e a enorme variedade de comportamentos possiveis de desenvolvimento econômico em séries temporais de longo prazo. Ao redefinir o conceito de armadilha nesses termos, propomos lançar luz sobre o contexto institucional do desenvolvimento econômico. Para avançar o argumento, realizamos um estudo de caso da América Latina, uma região que apresentou uma trajetória económica instável e não-linear ao longo do século XX. Argumentamos que a combinação entre o legado econômico colonial e a fragmentação política em meio ao processo de independência, moldou a estrutura socioeconómica $e$ as capacidades institucionais futuras da região, restringindo as possibilidades de superação do subdesenvolvimento.

\section{Palavras-chave}

armadilha da renda média, sistemas complexos, instituições, América latina, subdesenvolvimento.

Códigos JEL 010, 014, O33, B15, C32. 


\section{Introduction}

The world's economic history shows that long-term growth rates have fluctuated widely over time. While some countries have experienced stable growth trajectories, others have combined a relatively high growth period with long-lasting stagnation. Recently, economic literature has called attention to the existence of a "middle-income trap", a phenomenon that occurs when the economic growth rate fluctuates in a way that inhibits a middle-income country to upgrade to advanced-country levels of GDP per capita. Although a persisting growth slowdown is at the core of the trap, not all countries that face slow growth are trapped. On the other hand, not all countries that experience periods of high growth have been successful in escaping the trap.

Our intent is to enrich the debate on the dynamics of development trajectories by proposing a new method for depicting the pace, steadiness and other long-term properties that characterize the growth rate fluctuations. Specifically, we reinterpret the concept of trap using the language of the complex system approach to refer to the unpredictability, non-linearity and the enormous range of possible behaviors of economic development in the long-term time series. By redefining the concept of trap in those terms, we propose to shed light on the institutional background of economic development, since institutions are seen as an important condition for long-term economic predictability and stability.

In order to advance our argument, we conduct a case study of Latin America, a region that has presented an unstable and non-linear economic trajectory across the $20^{\text {th }}$ century. We argue that the combination between the colonial economic legacy and the political fragmentation amid the process of independence shaped the socio-economic structure and institutional capabilities for years to come, restricting the possibilities of overcoming underdevelopment.

The article is structured as follows. First, we advance a political economic approach for understanding the middle-income trap, highlighting the complex dynamics that underpin development trajectories. Second, in order to characterize this dynamic as a complex system, we carry out a quantitative historical experiment on long-term development trajectories, based on information extracted from the Maddinson Database. We seek to combine the quantitative evolution of indicators traditionally used in 
comparative analyses of development processes with measures that try to capture specific properties of those trajectories. In particular, we apply a Hurst exponent analysis to the per capita GDP data of a selected set of countries - which includes developed countries, Latin American countries and India - in order to differentiate in their development patterns.

Finally, we conduct a comparative historical analysis, contrasting the experiences of the United States and Latin American countries. As the decisive events in the region's independence process occur at the same time as the British Industrial Revolution was under way, the analysis emphasizes the initial impact of the first technological revolution on the region. Moreover, we discuss the political dimension related to the fragmentation and backwardness of the formation of nation states in Latin America. We argue that the combination of those elements inhibited the creation of the initial capabilities and institutions needed for technological learning, shaping the path of productive transformation that persisted in the region throughout the $20^{\text {th }}$ Century.

\section{2 “Middle-income trap" and complexity systems}

In Celso Furtado's theoretical elaboration on underdevelopment, Latin America is depicted as a case of a "trapped development trajectory" characterized by the combination between persistent technological backwardness and social mobility inertia. This idea of a "trap" has recently gained renewed attention in the literature as many former underdeveloped counterparts have come closer to the economic and social structures of advanced economies while Latin America remained relatively stagnated (Paus, 2014; 2017; Ribeiro at al, 2016).

The term 'middle-income trap' was first coined by Gill and Kharas (2007), in order to compare empirically the income evolution trajectory of different countries. It defines a situation in which a process of growth from low-income to middle-income levels - characterized by cheap labor, basic technology catch-up, and the reallocation of labor and capital from low-productivity sectors to high-productivity ones - eventually loses strength. While some studies find empirical evidence to support the existence of a middle-income trap related to growth slowdowns, other studies question the existence of a trap altogether. According to Agénor (2017), 
the arguments that have been put forward to explain the existence, and persistence, of middle-income traps include diminishing returns on physical capital, unskilled labor, poor quality of human capital, disregarding for the rule of law and intellectual property protection, lack of performance incentives, isolation and poor infrastructure, and lack of access to funding. This literature generally agrees that growth slowdowns are primarily led by a drop in total factor productivity, suggesting a range of policies to prevent the occurrence of this phenomenon associated with improvements in human capital, increased productivity and innovation.

These factors may be related to a comprehensive perspective of the determinants of the process of socio-economic development. In a Schumpeterian perspective, development comprises a process of structural change through which new activities emerge and others disappear, modulated by technological trends and socio-economic forces (Aghion; Bircan, 2017). One of the critical elements of this perspective refers to the cumulative and self-reinforcing character of historical trajectories that affect the patterns of socio-economic development. The lesson of Schumpeterian economics is that the impact of policies will be different, sometimes dramatically so, depending on technology, industrial organizational, and political economic structures.

In this regard, there is significant difference in how the issue of the trap is interpreted: a view focusing on the slowdown of growth or a more complex and structural change-oriented approach (Paus, 2014). Another point to extrapolate from the literature on the middle-income trap is that the impact of policies and institutions seems to be very context-specific, so crosscountry analysis is only able to indicate potentially relevant variables.

Sonobe (2019) advocates a framework that combines the political and economic aspects of middle-income countries. On the one hand, economists tend to blame the reason for slow growth on the low ability of the private sector to upgrade products, to rise productivity and to sophisticate the industrial structure. These analyses indicate that the countries that overcame these traps had, in general, more diversified, complex, and nonstandard export baskets at the time they were about to make the jump, as compared to countries stuck in the middle-income trap today. By contrast, political scientists tend to argue that industrial upgrading is difficult to achieve because of resistance and interference of incumbent firms that have political power (Chiarini et al., 2020; Doner; Schneider, 2019). 
In order to tackle the middle-income trap, Kang and Paus (2020) favor an integrated approach based on a 'political economy of development'. This perspective adopts a common set of assumptions: a) domestic productive capacities are fundamental for the development of innovations with a greater impact on productivity growth; b) the interaction between domestic and international factors changes over time and can reinforce the challenges for strengthening domestic innovative capacity; and c) the relations between the government and the private sector play a critical role in the development of domestic innovation capabilities.

This perspective also assumes that institutions required to sustain structural change and development can be seen as complex adaptive systems. According to Duit and Galaz (2008), complex adaptive systems are composed by agents that act using locally available information, self-organizing and evolving in a way that creates multiple possible future trajectories, limiting their systemic predictability. The pattern of changes of an economy would be highly path-dependent, with the complexity theory contributing to explain the "unbridgeable gap" between market behavior and equilibrium theory (Matutinovic, 2010). In this sense, it is possible to use "additional tools" to connect complexity theory and the approaches of new institutional economics by taking institutions that underpin systemic stability as a crucial component of complex system (Colander, 1996).

Another aspect that connects institutions with the properties of complex systems is their persistence or "resilience" over time, reflecting a historical process subject to evolution and entropy (Potts, 2007; Simmie; Martin 2010). This approach can be linked to a key defining feature of an institution: its semi-permanence (Hartwell, 2013). Yet, assuming that institutions are characterized by their resilience does not mean that they exist forever (especially in the political sphere). In this evolutionary process, inefficient institutions may die out and be overrun by "fit" ones; however, many "inefficient" institutions may survive long past their expected lifetime due to the reality of institutional inertia.

Specifically, the process of economic development can be accurately viewed as a complex evolutionary process, which does not need to be linear or historically determined. Connecting the institutional and evolutionary perspectives, the structural change inherent to the process of development refers not only to changes in the productive structure but also in the broad set of underlying institutions that condition the decisions of 
economic agents. For this reason, the effective understanding of this evolutionary process cannot be achieved without a historical analysis. Only history can tell the critical events and processes from which a specific arrangement has emerged, conditioning opportunities and limits of the development process. Maldonado (2011) argues that history as a whole can and should be viewed as a complex system, more specifically, a system of increasing complexity. The argument is that history operates as an open and a nonlinear system, which implies a complex density of time.

According to data prepared by Maddison (2010) and summarized in Figure 1, in the year 1700 the GDPs per capita of the United States and some Latin American countries (such as Mexico, Argentina and Brazil) were equivalent. However, from 1820 onwards, the United States per capita income stood out in relation to the levels of Latin American countries, reaching the double of the value presented by those countries in that year, and the triple by 1870. Considering this historical pattern of evolution, a recurring question in Latin American studies, and still with no conclusive answer, has been why did Anglo-Saxon America and Latin America follow such different development paths after independence and, even more relevant, why does Latin America persist in the same relative position in relation to developed economies.

\section{Figure 1 Evolution of GDP per capita (selected countries)}

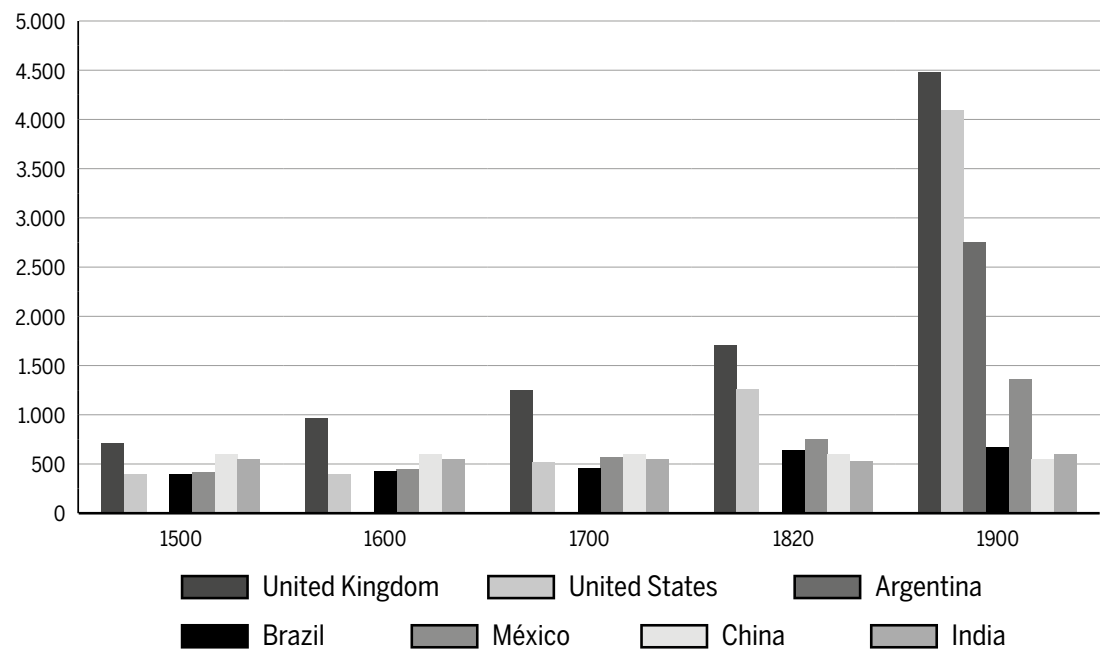

Source: Author's elaboration using data from Maddison (2010). 
However, the general movement of GDP per capita tends to conceal relevant contrasts between countries in terms of conditions of instability and the difficulties to build coalitions in each institutional context. In this sense, the trajectory of GDP per capita can either reflect random fluctuations, with low temporal correlation, or non-random fluctuations, with a self-correlated or self-organized nature. The use of measures of GDP per capita to capture development trajectories should, in this sense, be complemented by measures that capture the oscillations of this trajectory and its capacity to accommodate impacts of shocks in the socio-political-economic context.

In the next section, we propose an indicator to capture the capacity of complex systems to absorb shocks resulting from social, political and economic events and their impact on GDP fluctuations. The general hypothesis is that, on the one hand, self-organized systems are more stable and, therefore, generate less fluctuation. On the other hand, in non-self-organizing systems, the reaction to those shocks tends to be more random, reinforcing instability. Linking these properties of complex systems to the discussion of the development problem, it is possible to argue that the "middle income trap" is not necessarily related to stagnation, but to a random trajectory of a non-self-organizing nature that results in difficulties to cope with and accommodate shocks from different origins.

\section{Reassessing the trap: complexity system analysis and the Hurst Exponent}

In a nutshell, a complex system is formed by a large number of interacting components and exhibits different organizations at different scales of observation, which leads to different behaviors at different scales (Goldenfeld; Kadanoff, 1999). Regarding an economic system, the smallest possible level of disaggregation are the individuals that interact with other individuals (and other components of the system). Additionally, individuals are organized along specific groups, creating firms and other organizations (governments, universities, etc), which are more than an aggregation of individuals. The result (at this higher scale) is new institutions, such as laws, job training, public finance, stock market, (national) innovation systems, etc., which interact with individuals and groups, in different scales, generating a longlength correlation in the system that can be even equal to the system's size. 
Therefore, the global dynamics of the system is the result of the balance of a long chain formed by positive and negative feedbacks, in response to the change in the state of all elements of the system (local and smallscale disturbances) and their interaction with the environment in which it is inserted. This is the source of unpredictability, non-linearity and the enormous range of possible behaviors of complex systems. One possible interpretation is that the intricate relation of these interactions affects long-lasting socioeconomic factors and, more specifically, the rates and directions of accumulation of technological knowledge (Ribeiro et al., 2016), economic development (Hartwell, 2017) and economic traps (Zhou et al., 2018). In the context of this intricate puzzle the question arises: "what ultimately determines what?" (Smelser; Swedberg, 2005).

The answer might be what sociologists and historians have argued for long time: society is constituted in a complex system, self-referencing, self-organizing and self-producing (autopoiesis) that expands by increasing interactions with its own elements, in a continuously inflationary process of increasing complexity (Rodrigues, 2020). So, studying history as a complex system is a useful tool to understand the complex temporal fluctuations that characterize development trajectories (Maldonado, 2011). Our intent is to analyze the GDP per capita evolution in the $20^{\text {th }}$ century through these lenses.

\subsection{Maddison's per capita income data}

The comparative analysis of the long run determinants of the economic growth of different countries requires specific procedures for the historical reconstruction of the trajectories of the national income of these countries. The Maddison Database provided by the University of Groningen has greatly contributed to the understanding of long-run economic development through its Historical Statistics of the World Economy. In particular, for the period before 1950, this was the only database that provided systematic and broad cross-country information on comparative income and production levels (Jong e Palma, 2018; Maddison 1995, 2001, 2007).

The Maddison Database provides data on GDP per capita for comparisons of relative income levels across countries. In particular, these comparisons are based on information about 'real GDP per capita' calculated with 
reference to a common set of prices across countries (Bolt et al., 2018). The original analysis and Maddison $(1995,2001,2007)$ was prepared using original income data for different countries in the year 1990 as reference and then performing a historical reconstruction of GDP per capita growth rates to compare previous years. It combines modern-day and historical data, as well as structured time series, about the evolution of GDP per capita for different countries and regions, in order to build a comprehensive picture of this evolution, dating from Roman times to the present, constituting a powerful tool for historical comparisons.. The database has been constantly improved, and the most recent version introduced a new measure of real GDP per capita based on multiple comparisons of prices and incomes between countries. Thus, the resulting measure of real GDP per capita can be understood as based on constant prices between countries, which depends on the current reference year

This database has been widely used in comparative analyses of the historical evolution of countries as well as to discuss processes of structural change and catching up (Bassino; Van Der Eng, 2020; Gundlach; Paldam, 2019; Rosés; Wolf, 2018; Żuk; Savelin, 2018; Jones, 2016; Arias; Wen, 2016; Balcerowicz; Rzońca, 2015; Heikkinen; Nummela, 2015; Bolt et al., 2018; Fagenberg; Godinho, 2005).

\subsection{Random walks versus auto-correlated trajectories: the Hurst exponent}

In the second half of the $20^{\text {th }}$ century, several systems that did not show a smooth behavior fitting classical mathematical functions - as a straight line, a parabola, an exponential, a sinusoidal, etc. - started being studied (Nussenzveig, 1999). Even if these classical functions were augmented by adding random noise, they were not suitable to describe the erratic behavior of those systems. It is their non-linear property that strongly amplifies extreme subtle perturbations - like the flap of a butterfly's wings in Brazil - and thus transforms it, through a chain reaction, into a macroscopic change of the whole system - a tornado in Texas. As a result of this high dependence on radical perturbations in the system, its behavior is quite erratic and a new kind of mathematical function needed to be developed to deal with that behavior. 
To further understand the properties of that new kind of mathematical function it is necessary to understand what the dimension of an object means. So, consider a segment of a straight line that can be represented as a piece of a straight wire of a given material (see Figure 2a). If this piece of wire is cut in half, one obtains two smaller versions of the original wire, or, more precisely, two versions with half of the original length and mass. The smaller versions of the original wire can be seen just as a rescaled version of it, i.e., if 2 times zoom is implemented in the smaller version exactly the original version is obtained. Therefore, the smaller version is the original one rescaled by a factor of $\frac{1}{2}$ that can be mathematically written as $l=\frac{1}{2} L$ were $L$ is the original length of the wire and $l$ its rescaled one. As discussed above, the mass of the wire is also rescaled by a factor of $\frac{1}{2}$, therefore, $m=\frac{1}{2} M$ where $M$ is the original mass of the wire and $m$ its rescaled one.

Figure 2 Definition of integer dimension

(a)

L

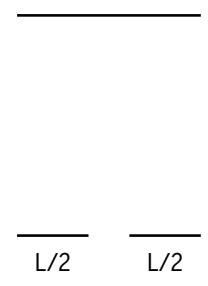

(b)

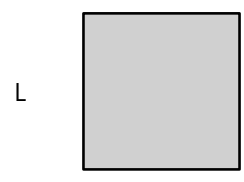

$\mathrm{L} / 2$

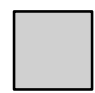

$\mathrm{L} / 2$

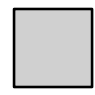

$\mathrm{L} / 2$
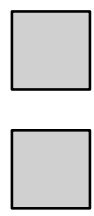

$\mathrm{L} / 2$ (c)
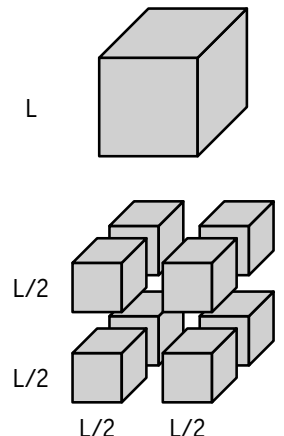

Source: Author's elaboration.

Now, instead of thinking on a wire let us consider a squared sheet of a given material and also rescale it by a factor of $\frac{1}{2}$, i.e., cut each side in half (see Figure $2 \mathrm{~b}$ ). This time, one obtains four pieces that are rescaled versions of the original sheet. But now, to recover the original mass it is necessary to 
join the four pieces, therefore, the mass of each one is $\frac{1}{4}$ of the original mass. So, for a squared sheet, when it is rescaled by a factor of $\frac{1}{2}$ its mass is rescaled by a factor of $\frac{1}{4}$, i.e., $m=\frac{1}{4} M$ or $m=\left(\frac{1}{2}\right)^{2} M$.

Finally, let us consider a cubic piece of a given material and also rescale it by a factor of $\frac{1}{2}$, i.e., cut each side in half (see Figure $2 \mathrm{c}$ ). This time, one obtains eight pieces that are rescaled versions of the original cube. But now, to recover the original mass it is necessary to join the eight pieces, therefore, the mass of each one is $\frac{1}{8}$ of the original mass. So, for a cube, when it is rescaled by a factor of $\frac{1}{2}$ its mass is rescaled by a factor of $\frac{1}{8}$, i.e., $m=\frac{1}{8} M$ or $m=\left(\frac{1}{2}\right)^{3} M$ Putting all equations relating the rescaled mass with the rescaling factor, one obtains:

- in one dimension (wire): $m=\frac{1}{2} M$

- in two dimensions (sheet): $m=\left(\frac{1}{2}\right)^{2} M$

- in three dimensions (cube): $m=\left(\frac{1}{2}\right)^{3} M$

Due to the similarity of those equations, they can be written as just one equation, $m=s^{D} M$ where $s$ is the rescaling factor $(1 / 2$ in the previous examples) and $D$ is the dimension of the object. Therefore, the dimension of an object is related to how it fills space when it is rescaled. Objects with an integer dimension are those with which classical mathematics deals and the ones we are used to dealing with daily.

However, it is possible to construct objects that have a non-integer dimension. To figure out how this is possible, imagine a curve built following these steps:

a) start with a segment of a straight line;

b) split this segment into three pieces of the same length;

c) remove the intermediate segment;

d) replace it with two segments, each one showing the same length of the previous, forming two sides of an equilateral triangle. 
By following those steps, it starts from $I=0$ in Figure 3 and goes to $I=1$. Then, the complete curve is built as an iterative process by repeating steps 1 to 4 to each segment of line left in the previous curve. Thus, $I=2,3,4$ and so on in Figure 3 were built. This process needs to be repeated a huge number of times (mathematically, infinite times) to obtain the so-called Kock curve.

Figure 3 Building the Kock Curve

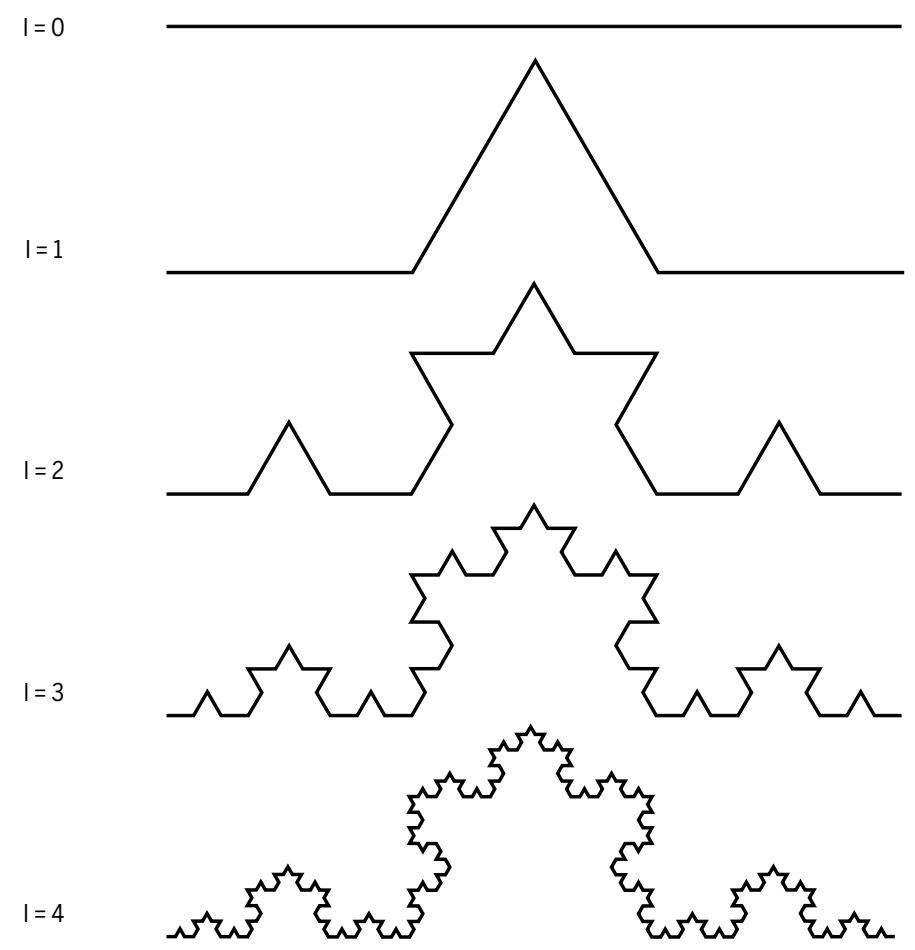

Source: Author's elaboration.

If the Kock curve is rescaled by a factor of $1 / 3$, as shown in Figure 4 , one obtains $1 / 4$ of the original curve, therefore $m=\left(\frac{1}{3}\right)^{d} M$, and $\left(\frac{1}{4}\right) M=\left(\frac{1}{3}\right)^{d} M$. As the mass is not null, it can be written as $3^{d}=4$ and, finally, getting the log of both sides, $d=\frac{\log 4}{\log 3} \approx 1.26$. Therefore, the dimension of the Kock Curve is 1.26 , which is not an integer. The curves that 
have a non-integer dimension are called fractals and their dimension, fractal dimension.

Figure 4 Fractional dimension of Kock curve

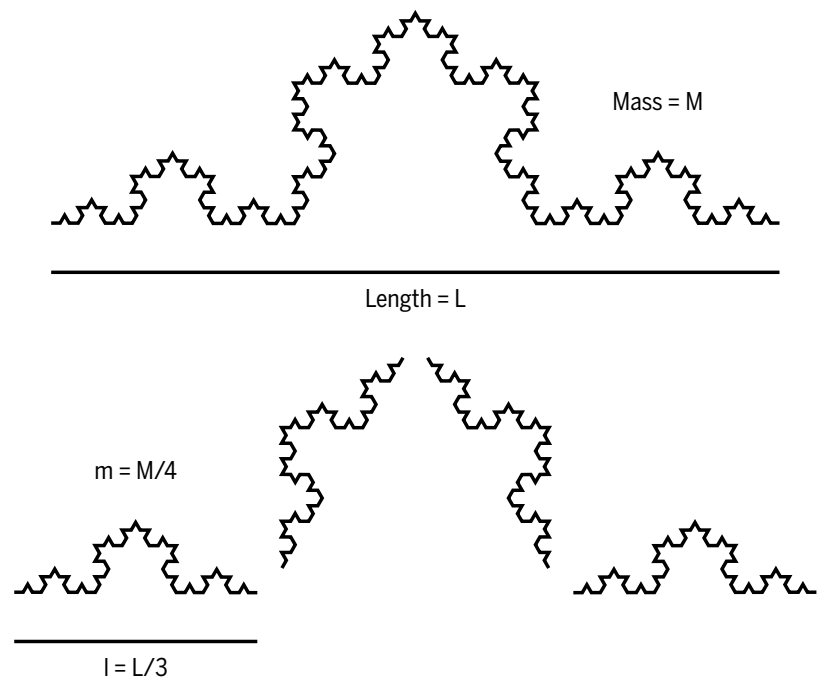

Source: Author's elaboration.

The property of the rescaled curve or object being similar to the original one is called self-similarity, and is that which allows the calculation of the dimension of that curve or object, either integer or fractional. The objects of the previously discussed examples have the self-similarity property as a straight consequence of how they are defined. How to deal with objects that are not previously known to be self-similar, though? To tackle that, think of England's coast, that shows a quite rough shape (Figure $5 \mathrm{a}$ ). What is the dimension of the curve that contours the England's coast? To answer that, it is necessary to calculate the relation between its rescaled area and the original one. As this curve is not a physical object, the definition of its mass is abstract and arbitrary. It is thus suitable to define that the curve's mass-density equals 1 , so its mass becomes equal to its area. Defining the area of a curve is much easier; it is just necessary to cover the curve by a grid (see Figure 5b), to count how many squares touch the curve and to multiply it by the area of each square. 
Figure 5 Re-scaling the England cost

(a)

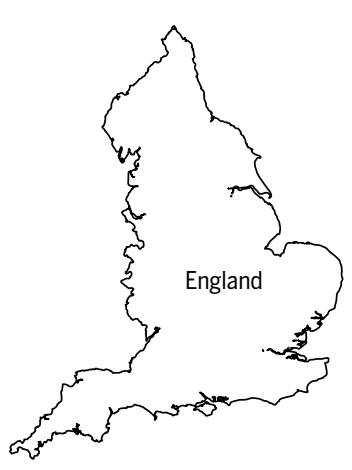

(b)

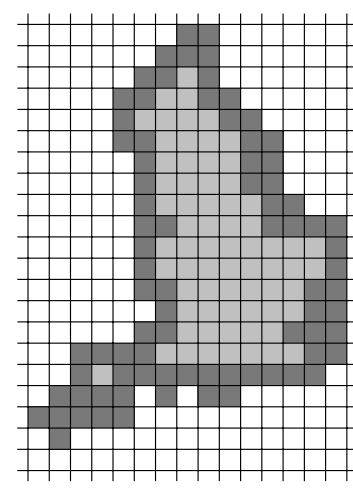

(c)

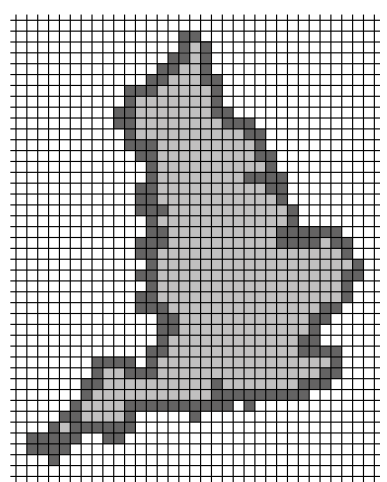

Source: Author's elaboration.

However, what matters in the calculation of the dimension is not the area (mass) itself, but its relation when the curve is rescaled. It is possible to think about the rescaling in two ways: the more direct one, to keep the grip fixed and to zoom in or out the curve; or to keep the curve fixed and to zoom in or out of the grid. These two processes are entirely equivalent. In Figure $5 c$, the grid was zoomed out (equivalent to zooming in the curve) and the area of the rescaled curve is the number of squares that it now touches. And, finally, consider the relation among the rescaled mass, the rescaling factor, and the dimension $m=s^{D} M$, starting from a grid with a unitary distance between the lines and rescaling it for different factors. When the grid is zoomed out, the curve is zoomed in, so there is an inverse relationship between the grid's and the curve's rescaling factor, therefore, a rescaling factor of $s$ in the curve corresponds to a rescaling factor of $s^{-1}$. Thus,

$$
N(l) \propto l^{-d},
$$

where $N$ is the number of squares that touch the curve, $l$ is the grid rescaling factor and $\propto$ indicate that it is a proportion (actually, from the number of squares of the original unitary-sized grid).

Therefore, there is a power-law relation between the number of squares and the rescaling factor and its exponent is the dimension of the curve. So, 
the dimension can be calculated rescaling the grid by several different factors, calculating the number of squares that touch the curve in each grid size, and regressing a power-law function to the data obtained.

From this equation of the number of squares touched by the curve, it is straightforward to calculate the area of the curve by multiplying the number of squares by its area, that is, $l^{2}$ for this two-dimension example or $l^{D}$ for the general case where $D$ is the dimension of the space in which the curve is embedded. Therefore:

$$
A(l) \propto l^{-d} l^{D}=l^{D-d}
$$

In addition, as the standard deviation is a way to calculate the average width of a curve, the variance can also be used to calculate the area of the curve (Moreira, 1994; Ivanova, 1999; Govindan, 2001; Costa, 2003; Sales,1997). It is just necessary to adapt the definition of the variance to calculate it within an interval $l$

$$
\sigma^{2}\left(x_{0}, l\right)=w\left(x_{0}, l\right)=\frac{1}{l} \sum_{x=x_{0}}^{x_{0}+l}(f(x)-\bar{f}(x))^{2}
$$

where $x_{0}$ is the initial point of the interval $l, f(x)$ is the curve at point $x$ and $\bar{f}$ the average of the curve within the interval.

Finally, the average over the initial point of the interval $l$ is calculated obtaining:

$$
W(l)=\frac{1}{N} \sum_{x_{0}=1}^{N} W\left(x_{0}, l\right)
$$

That is called roughness and is also a measure of the area of a curve as a function of its scale $l$ as it comes from the variance of the curve that also is a measure of the area of a curve. Therefore, it inherits the same power-law relation with $l$ as the number of squares covered by the curve discussed above, and its exponent is called the Hurst exponent $H, W(l) \propto l^{H}$. Comparing it with the relation $A(l) \propto l^{D-d}$.,

$$
H=D-d
$$

where $H$ is the Hurst exponent, $D$ the dimension of the space in which de curve is embedded and $d$ is the dimension of the curve. 
Therefore, the Hurst exponent is directly related to the dimension of a self-similar curve and reflects the curve's structure as a whole - not just part of it. As it is related to the fractal dimension, it represents the exponent of the rescaling factor of a self-similar curve.

Furthermore, the Hurst exponent is also related to the autocorrelation in the curve. By using the self-similarity property involving the Hurst exponent, $f(x)=s^{H} f(s x)$, and the definition of autocorrelation $R(\tau)=E$ where $E$ indicates the average, it is possible to show that,

$$
R(\tau)=2^{2 H-1}-1
$$

Then, the autocorrelation is independent of the interval $\tau$ that separates the points where the correlation is calculated. It makes the autocorrelation length go to infinity, i.e., being the same length of the whole curve. And,

- $R(\tau)>0$ if $H>\frac{1}{2}$, therefore the curve is positively auto-correlated it means that a point in the curve is positively correlated to a previous one, i.e., they follow the same tendency; it creates smoother curves with a clear tendency of increasing or decreasing;

- $R(\tau)=0$ if $H=\frac{1}{2}$, the curve is not auto-correlated - it means that a point in the curve is not correlated to a previous one, therefore it is equivalent to a random walk;

- $R(\tau)<0$ if $H<\frac{1}{2}$, the curve is negatively auto-correlated - it means that a point in the curve is negatively correlated to a previous one, i.e., they follow opposite tendencies, if the previous point decreases the further point increases and vice-versa; it creates quite rough curves without a clear tendency of increasing or decreasing;

So, by analyzing the Hurst exponent, which captures the global structure of the curve, one investigates the property of the curve related to its autocorrelation for all different intervals. Furthermore, there are some curves whose self-similarity exponent, i.e. the Hurst exponent, is not the same for all rescaling factors. So, those curves rescale in different ways for different scales. For example, they can rescale according to an exponent $H_{s}$ where small rescaling factors are used - small changes are made on the curve - and according to an exponent $H_{l}$ when large rescaling factors are used big changes are made. 
Those curses are called multi-fractals and, as a consequence of their self-similarity properties, they show different Hurst exponent on different scales.

\subsection{The Hurst Exponent of modern economic growth: a new mea- sure for the middle-income trap}

The Hurst exponent can be used as a measure of the long-term memory of time series. Despite having a broader temporal horizon, Maddison's data make available the year-by-year GDP for several counties just after 1900 . As the aim of this study is to compare several countries and considering that the Hurst exponent analysis requires detailed data covering a long interval, the decision was made to limit the analysis to the interval between 1900 and 2008.

Several countries, covering central and peripheral ones, were selected to implement the Hurst exponent analysis to their GDP per capita data. The full list of analyzed countries is the United State, Austria, Belgium, Denmark, Finland, France, Germany, Italy, the Netherlands, Norway, Sweden, Switzerland, the United Kingdom, Portugal, Spain, Australia, New Zealand, Canada, Argentina, Brazil, Chile, Colombia, Mexico, Peru, Uruguay, Venezuela, India, and Japan.

The roughness of all different scales, as discussed in section 4.2, was calculated for those countries from 1900 to 2008. Figure 6 shows the obtained relation between the roughness and the interval length in a log-log scale for the USA and Venezuela. ${ }^{1}$ As a log-log scale is used, the power-law behavior becomes a linear one and its slope the exponent of the power-law, i.e. the Hurst exponent $(\mathrm{H})$. Thus, linear regressions were implemented to calculate the slope in different ranges. As different slopes - Hurst exponents - were found, the temporal evolution of the GDP per capita of those countries are multi-fractals. For the USA, we identified three different intervals with dif-

1 To illustrate the Hurst exponent calculation showed in Figure 6, the USA was chosen as the representative of developed countries because it was the capitalist leader country during a major time of the analyzed period and it shows a quite high GDP per capita. And Venezuela was chosen because it is representative of developing countries, and, in opposition to the USA, shows a quite low GDP per capita. So, the intent was to highlight the roughness behavior of two distinctly different trajectories. Only two countries were presented in figure 6 to make it cleaner, but the roughness behavior and its associated Hurst exponent was calculated for all analyzed countries as shown in figure 7. 
ferent Hurst exponents, i.e., rescaling properties and autocorrelation, up to 16 years, from 16 to 50 years and greater than 50 years. In the short term - first interval - the USA's H is 0.65 and Venezuela's H is 0.48 , so, the USA has a positive autocorrelation while Venezuela has an almost null (-0.03) one in that time range. In the long term - third interval - both countries have positive autocorrelations, however, the USA has a greater one (correspondent to $\mathrm{H}=0.94$ and $\mathrm{R}=0.84$, while Venezuela has $\mathrm{H}=0.78$ and $\mathrm{R}=0.47$ ). In the medium term, both countries have similar positive autocorrelations.

Figure 6 Roughness and the interval length in a log-log scale

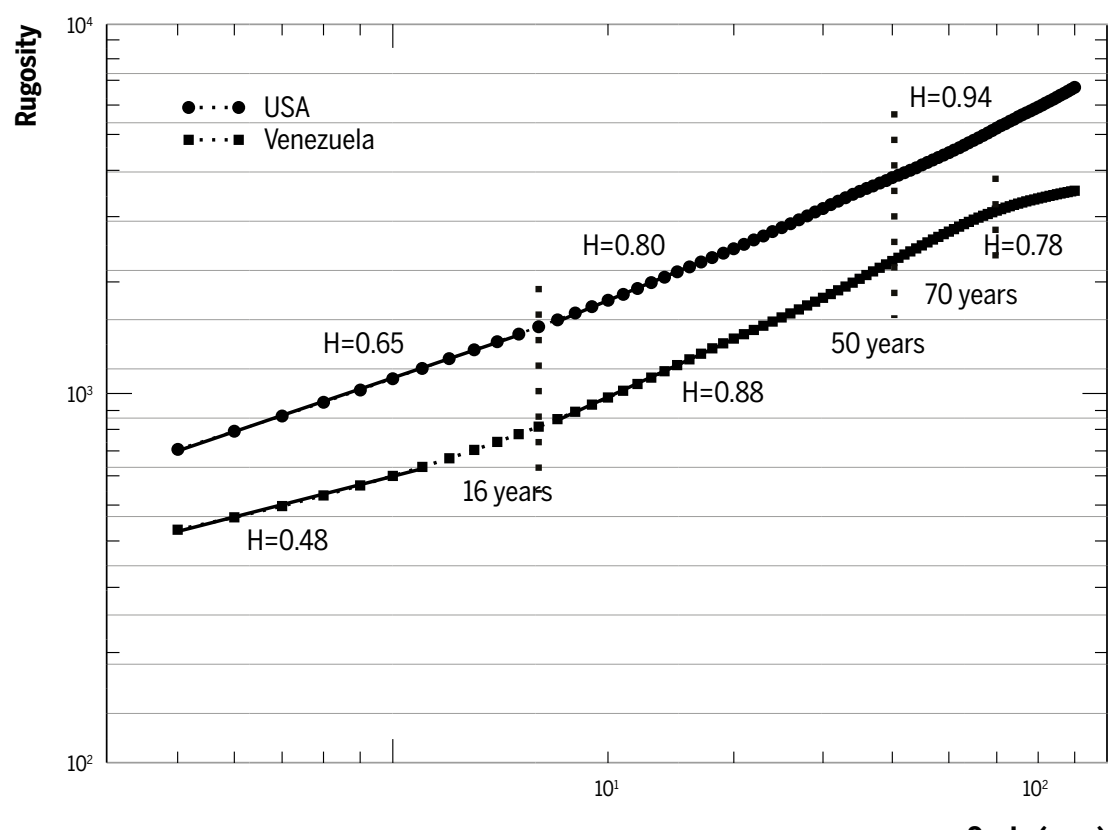

Scale (year)

Source: Author's elaboration.

The comparison between the USA and Venezuela illustrates the behavior of autocorrelation of GDP per capita over the long term. In the short term (considering an interval of 16 years), the USA presents a positive autocorrelation, which means that its economic path is more persistent. Venezuela, in contrast, presents an almost null autocorrelation, meaning that its trajectory is quite random in the short term. Only in the medium and long term does the economic trajectory of Venezuela show a more 
persistent path. Considering this initial finding, the next step is to explore if this difference in the short term is a common property among developed economies and Latin America.

The analysis was then expanded to include the other countries and their Hurst exponents were calculated in the short term (up to 16 years); they are shown in Figure 7. Visually, it can already be seen that the central countries have higher values of $\mathrm{H}$ while Latin America plus India have lower values of $H$. It seems that the threshold of 0.63 is a value that separates the group of the central countries from the group of Latin America plus India. These differences indicate that the Latin America plus India trajectory tends to be more random when compared to developed countries.

Figure 7 Hurst Exponents

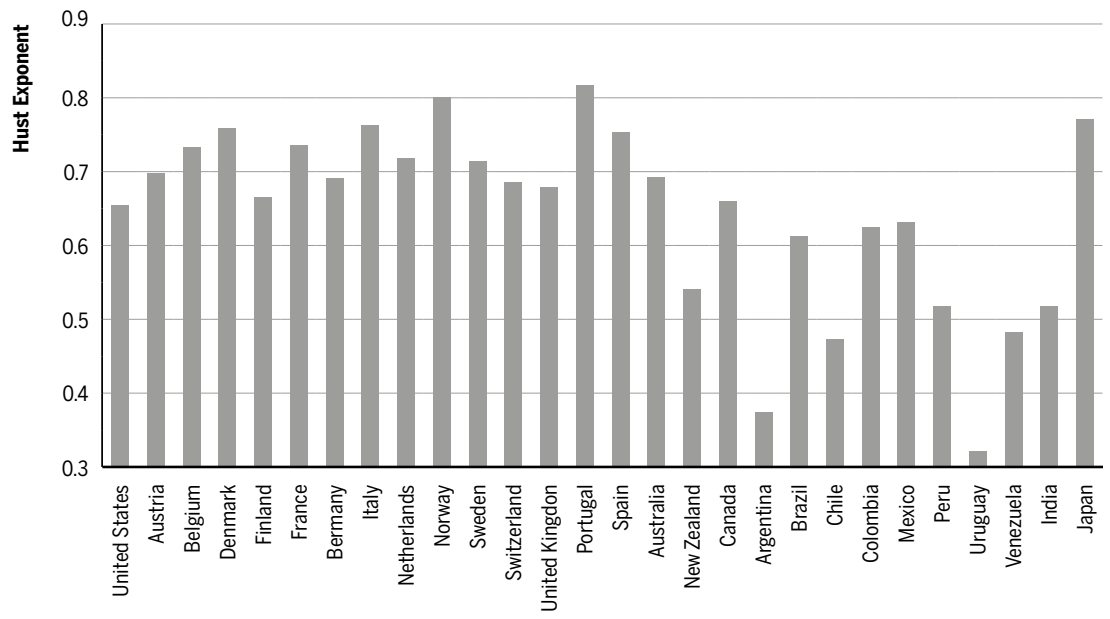

Source: Author's elaboration.

To test this visual aspect statistically, i.e., see if the Hurst exponent can separate the central countries from Latin America plus India, a boxplot was made and it is shown in Figure 8. The boxplot shows the following information: the minimum and maximum values of $\mathrm{H}$ represented by the error bars; the $1^{\text {st }}$ and $3^{\text {rd }}$ quartile represented by the starting and ending lines of the box respectively; the median represented by the horizon line inside the box; and the average represented by the $\mathrm{x}$ inside the box. The distance between the boxes corroborates that the Hurst exponent can be used to distinguish the two groups. 
Finally, to show statistically that the groups can be distinguished using the Hurt exponent, a hypothesis test was performed considering the null hypothesis as the difference of the two groups being different of zero. The results show, with a confidence of $99 \%$, that they are different groups.

Figure 8 Hurst exponent - boxplot

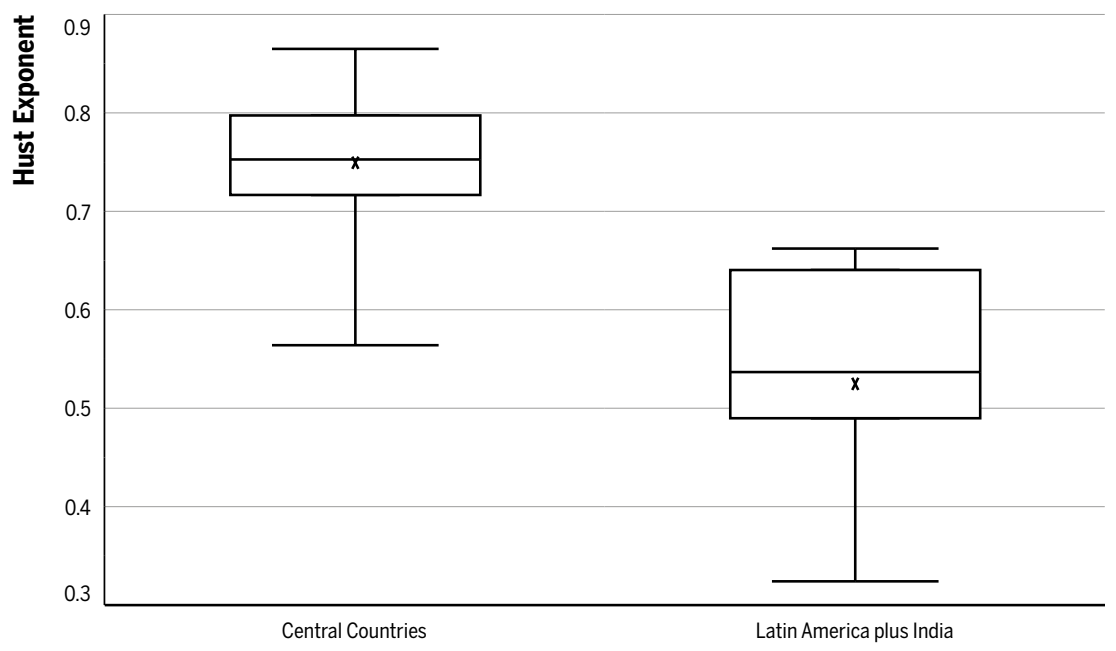

Source: Author's elaboration.

Therefore, an important finding emerges from the analysis: the properties of the economic trajectory of developing countries differ from those of the trajectory of developed economies when zoomed in a short-term scale. This result suggests that the underdevelopment trap can also be depicted by the lag between different levels of economic development in the longterm time series. More research needs to be done for applying the Hurst Exponent in different scales. For the moment, the analysis reveals that this method brings a promising measure for understanding the implications of long-term economic growth for the middle-income trap.

\section{Latin American historical roots: industrialization and political fragmentation}

Initial conditions matter for long-term development. Yet, Scholars of Latin 
America's economic history have not come to terms on the debate whether the great divergence observed in the $20^{\text {th }}$ century originated in the colonial or in the national period. One can say that Latin America was already behind at the time of independence, yet events that marked the formation of national states, during the decades after 1770, created a critical juncture, establishing certain directions of change and foreclosing others in a way that shaped the institutional capabilities for years to come (Hensell, 2003).

Following a prominent scholarship on catch up processes (List,1848; Gerschenkron 1962; Freeman,1995; Atack; Passell, 1995; Amsden, 2001; Wood, 2003), we argue that state-building is the preliminary stage to develop the institutional capacity to support industrialization and technological upgrading. Rather than offering thick history accounts, the narrative provided below intends to make more explicit the historicity of the interplay between the economic and political dynamics that compounds the roots of the Latin American trajectory.

\subsection{The Economic background for industrial revolution}

The Industrial Revolution transformed the face of our planet. Marx mentions a new international division of labor and Celso Furtado refers to it at the origin of the modern center-periphery division, stressing the need to understand the new conditions created by the English Industrial Revolution and its impacts on Latin America (Furtado, 1970, p. 38). Economic historians generally agree that Latin America lacked the capitalist conditions for industrialization, although for different reasons. ${ }^{2}$ The explanations for the industrial failure in the region are numerous.

First, the dynamics of industrialization in the European metropolises had inevitable consequences for Latin America. In the assessment made by List (1848, p. 86), in the middle of the $19^{\text {th }}$ century, Spain and Portugal were already behind, stagnated in the first stage of development, considered by him as a "state of barbarism". The only alternative for "barbarians", according to List, was to resort to free trade in order to achieve some progress in agriculture. Great Britain, in turn, would be at the most advanced stage of manufacturing production and, therefore, should encourage the

2 For the absence of manufactures in Brazil, see Suzigan, 2000, pp. 82-83, for the United States, see Atack and Passell, 1996, p. 55. 
opening of markets for its products. Intermediate states, however, such as the United States and Germany, would need tariff protection to boost their nascent industries.

In this sense, a crucial variable refers to the capacity of absorption of the new technologies deriving from the rise of industrialization by the metropolises themselves, given that the initial unfolding of the Industrial Revolution happened under the imperial rule. While some latecomers in Europe, in particular Germany and France, developed specific policies to foster manufacturing and assimilate the new techniques, Portugal and Spain opted for intensifying the economic exploitation of colonial economies in order to make them pay for the increasing demand for industrial goods.

The strategy of the Iberian empires was to implement tax and regulatory policies in the colonies. Fearing imperial decline, the Spanish crown initiated the Bourbon reforms, which intended to limit the power of the creole elites and increase taxation on commercial agricultural and mining (Simon, 2017). In the same vein, Portugal instituted the "derrama", an additional tax on gold to satisfy the royal demands amid the decline of the gold mining in Brazil in the 1750s (Paula, 1984). These measures inhibited the processes of accumulation needed for industrialization in the colonies, by raising start-up costs and risks, immobilizing people and capital, and distorting market signals to maximize revenues (Bulmer-Thomas et al., 2008).

Second, the resilience of slavery is also considered an important block for industrialization in the region. With the decline of mining, the cotton, sugar and slavery economies became the most profitable business in the Iberian colonies and remained relevant even after independence (Turtino, 2016). The reasons are twofold. First, a slavery economy inhibits the creation of a robust consumer market, limiting the demand for manufactured products to a tiny elite, which are prone to import from international markets. The second reason relies on a more encompassing view of capitalist dynamics. The slavery system inhibits the flexibility of the labor markets, which is an important condition for increasing productivity and competition in the international markets. Under a rigid system of labor turnover, the conditions for entering new activities or extracting added value from labor were very limited (Paula,1984). 
In the North America, by contrast, the mix of free labor, in the Northern colonies, and slavery, in the Southern plantations, created the conditions for accumulation, reproducing the central-periphery dynamic at the local level. At the onset of the industrial revolution, the cotton and slavery economies in the South were linked to British manufacture. After the USA independence, however, the cotton production began supplying the mills from the Northern part of the country, giving birth to a nascent industry and a continental economy.

Third, Latin America not only lacked domestic dynamic elements for embracing industrialization, but also the international conditions. Under the aegis of the "British world-system", which was consolidated between the 1830s and 1870s, combining military, commercial and financial elements with a technological revolution, the United Kingdom managed to expand its economic and political influence beyond their colonies, representing a global power structure, conceived as an "octopus power" (Darwin, 2009, p. 64).

Facing the loss of space in international trade for British manufactures, Portugal and Spain's last strategy was to act as a trade broker of industrial goods for the colonies. Yet this position was rapidly replaced by the British and North American merchants after independence (Novais, 1979). Under British hegemony, the free-trade policy was endorsed, reducing the role of Latin America to the position of supplier of agricultural goods, through which the Anglo-Saxonian world could "fully benefit from the lower prices of raw materials resulting from the reduction of maritime tariffs" (Furtado, 1970, p. 51) . $^{3}$

In a nutshell, the Industrial Revolution reached Latin America in a moment when the region as a whole was unable to take advantage of the opportunities opened up by the Revolution, contributing to consolidate its peripheral position in the international system. Although the economic conditions in Latin American changed after independence, domestic and international constraints inhibited the development of the institutional capabilities needed for industrialization. Mostly importantly, the abolition of slavery was not completed de jure until the end of the $19^{\text {th }}$ century, limiting the expansion of the labor market and of the capitalist dynamism.

3 This trade dynamic has been fully examined by the Dependency theory and World System theories as the core of the underdevelopment processes (Santos, 1999). 


\subsection{The political dimension: fragmentation and backwardness in the formation of nation states in Latin America}

It was not before 1870 that new independent states in America were consolidated (Turtino, 2016). Historical accounts of different paths of postindependence British and Iberian former colonies commonly contrasts the unification of the United States, on the one hand, and the great fragmentation of the former Spanish empire, on the other. Central America was separated from Mexico in 1823 and, sixteen years later, was already divided into 5 states (El Salvador, Costa Rica, Honduras, Nicaragua and Guatemala). In 1830, "Greater Colombia" became Venezuela, Ecuador and New Granada - the latter was dissolved in 1903, with the independence of Panama from Colombia. The union between Peru and Bolivia was dissolved in 1839. In the Plata region, Uruguay, Paraguay, Bolivia and Argentina were created. Fragmentation was accompanied by countless territorial conflicts, which extended into the $20^{\text {th }}$ century.

This divergent aspect alone gives the false impression that only the latter saw themselves struggling with separatist conflicts and contradictions. Yet, a more detailed assessment shows that contradictory elements could be seen across the entire region after independence. The power concentrated in the northeastern United States sharply contradicted with the subordinated south as the country only came together after the Civil War, in 1865. ${ }^{4}$ As in Latin American newly independent countries, the postcolonial United States also saw a fault line between local-oriented elites and national supporters of a central government (Turtino, 2016).

What seems to be the key to the great divergence relates more to the way that each country has overcome local rivalries and combined forces to build institutional capacities rather than the absence of contradictions. As systematized by the technological change literature (Cohen and Levinthal, $1989,1990)$, the key variable for the diffusion of new technologies is the "absorptive capacity", something that would be the main task of innovation systems in the periphery. These institutional arrangements, even in their initial rudiments, depend on public sector action, which did not exist in Latin American colonized countries or emerged later on in the process of state consolidation. Some important obstacles inhibited the creating of sented by United States, and "holding-together" model see: Stepan, 1999. 
these institutional conditions at the onset of independence.

First, the political fragmentation and territorial conflicts had important consequences for the economic trajectory of the newly independent states. Escosura (2006) assesses that the administrative costs resulting from the multiplication of political units after independence exceeded the gains obtained with the reduction of the tax burden of the Spanish Crown. In other words, the foreign currency previously sent abroad was quickly absorbed for maintenance of the local administrative apparatus, inherited from the colonial times.

In the United States, the former thirteen colonies, which had previously enjoyed considerable local administrative and tax autonomy, joined together for building what they called a "republic empire," envisioned by the country founders to pursue territorial expansion against the British power (Rothman, 2016). The occupation was not without conflict, especially with the incorporation of Mexican territories. The idea was to promise the western colonies equal political rights to self-government in order to contain separatist turmoil under the white northeast supremacy.

Second, territorial disputes further deteriorated the fiscal condition of the new states. While the expansion of military spending in the USA was funded by the republic's nascent fiscal budget, in Latin America it was mostly financed by the British capital. Centeno (2002) argues that territorial disputes in Latin America amid the subordination to hegemonic interests (British Pax) resulted in bloodshed and an increased debt.

Third, in Spanish America, political fragmentation was accompanied by commercial, monetary and financial disintegration among the former colonies. In commerce, the colonial administration obtained advantages from economies of scale, but with the separation, there was loss of efficiency with the duplication of efforts to guarantee property rights and infrastructure. If intra-regional trade was already insignificant, the creation of tariff barriers further reduced the incentives for production diversification. In addition, the fragmentation of monetary administration increased the obstacles for trade, creating additional costs. In the financial aspect, while the United States joined forces to create public sources of financing, Latin American countries turned to English banks, which marked the beginning of a long path of foreign indebtedness.

In the USA, a unified and continental domestic market, and articulated by the revolution in transports and communications in the $19^{\text {th }}$ Century, as 
analyzed by Chandler (1977, p. 79-206), made available the bases for economies of scale and scope. Market unification led to the structural transformations of the companies - that became big multiunit business enterprises $^{5}$ - and of the market itself - that became oligopolized by the action of pioneer firms that took advantage of the economies of scale and scope. The managerial revolution at the root of the multiunit companies can be considered one of the prerequisites for the emergence of the multinational companies - basically multiunit businesses with at least one operating unit abroad. The rise of the modern enterprise in a leading economy, like that of the United States, will pose extra challenges to the late industrialization of Latin American economies, defining one the main features of the peripheral capitalism: the strong presence of transnational companies in strategic sectors of national economies.

The fourth obstacle, and related to the previous point, is the link between political fragmentation and the pattern of insertion in the international division of labor. Escosura (2006) suggests an articulation between the two elements: "links between regions of the Central American Federation weakened as export orientation increased. Together with political instability, this led to the creation of five new countries in 1839" (p. 489). Furtado (1970) argues that the evolution of the Latin American socioeconomic structure, in the context of the international division of labor in the colonial period and in the first phase of industrialization, helped to foster regional fragmentation.

In the same vein, a significant difference concerns the role played by England in the post-independence period. While in the United States it was necessary to look for ways to compete with England, in the former Spanish and Portuguese colonies England came to replace the metropolises in accessing the European market and in financing the independence processes. At that time, an imperialist relationship with the hegemonic economy was created, which, a century later, would be replaced by the United States. In addition, the commercial and financial relationship built with England, during the $19^{\text {th }}$ century, postponed the incentives for the industrial revolution in Latin America, since the region functioned as one of the main markets for English products. 
Thus, the economic role assumed by England has distinct political and economic implications for the United States and for Latin America. While in the former the increasing competition created incentives for the unification and construction of a strong state, in the later the political collaboration and economic integration with England reinforced regional disintegration.

In the United States, there was a clear understanding of the role of the state. Although many leaders of American independence were influenced by Adam Smith's ideas, there was an understanding among the nation's "founding fathers" about the need for a strong state to encourage capital accumulation and economic development. In this sense, the new country managed to balance local administrative responsibilities with the implementation of "self-strengthening" policies to enhance national autonomy, promoting "migration, commercial development, and national integration, including the creation of a regulated real estate market, a postal network, and other infrastructural projects that promoted the transportation of people, goods, and information back and forth between interior communities and the Atlantic world" (Rothman, 2016, 117).

In contrast, in Latin America, the external and internal political context reinforced institutional fragilities. Specifically, amid the absence of a strong administrative authority, local and centrifugal forces prevailed over the centrality of the state, endorsing the power games of local elites. The rules were elaborated and changed according to the interests of the victorious groups, creating institutionally unstable environments, not favorable to efficient economic organization. Not even the legitimate control of the use of force was a state prerogative, since local elites maintained parallel systems of protection. There was, therefore, resistance from the elites in delegating authority to the central power.

Therefore, the combination of those elements generates a very specific vicious circuit in Latin America, perhaps the most important component of a trajectory that persists throughout the $20^{\text {th }}$ century.

\section{Conclusion}

Our main finding was that the overall dynamics of GDP per capita in the $20^{\text {th }}$ Century differentiate India and Latin American countries from the central capitalist countries according to their level of persistence: the tra- 
jectory of middle-income and low-income economies tends to be quite random in the short-term. The lack of a persistent economic trajectory can also be interpreted as an absence of organized behavior among economic agents, which cannot be disentangled from the absence of an institutional background able to coordinate and generate endogenous development.

The lack of robust institutions goes back to the $19^{\text {th }}$ Century. The historical trajectories of Latin American countries after the independence processes point to three combined processes: political fragmentation, inexistence of an institutional arrangement capable of absorbing the new technologies derived from the Industrial Revolution, and a passive integration into the international division of labor reconfigured by the Industrial Revolution. These three combined processes define an economic trajectory that can be described as an underdevelopment trap, which, more recently, has become conceptualized, based on comparative criteria with other countries, as a "middle-income trap".

Our findings enhance the arguments presented by CEPAL and OECD in the Latin American Economic Outlook (2019) Report. According to them, Latin American and Caribbean countries would tend to face "new" development traps that act as a barrier to further inclusive and sustainable growth, creating "vicious circles" that limit the capacity of Latin American countries to move towards higher levels of development. The Report highlights the existence of four main development traps: the productivity trap, the social vulnerability trap, the institutional trap and the environmental trap. These interlinked traps would be particularly relevant in a rapidly changing global context, which poses new and increasingly complex challenges. In this sense, despite some of these traps assume a "new" character, we can also argue that most of them reflect a long-term historical process through which social, economic and political conditions combine and mutually reinforce each other. The historical characterization of the properties of these trajectories - revealing their similarities and specificities - forms the basis of a research agenda encompassing contributions of researchers from different backgrounds to the understanding of the Latin American reality. 


\section{References}

AGHION, P; BIRCAN, C. The Middle-Income Trap from a Schumpeterian Perspective. ADB Economics Working Paper Series 521, Asian Development Bank. 2017.

AMSDEN, A. The rise of "the rest": challenges to the West from late-industrializing economies. Oxford: Oxford University. 2001.

ARIAS, M.; WEN, Y. Relative Income Traps. Federal Reserve Bank of St. Louis Review, First Quarter, V. 98, n. 1, pp. 41-60, 2016

ATACK, J.; PASSELL, P. A new economic view of American history. New York: W. W. Norton. 1996.

BALCEROWICZ, L.; RZONCA, A. The Significance of Economic Growth. in Balcerowicz, L.; Rzonca, A. eds. Puzzles of Economic Growth. Directions in Development. Washington, DC: World Bank. doi:10.1596/978-1-4648-0325-3. 2015.

BASSINO, J.P.; VAN DER ENG, P. Asia's 'little divergence' in the twentieth century: evidence from PPP-based direct estimates of GDP per capita, 1913-69, Economic History Review, 73, pp. 185-208. 2020.

BERNERS-LEE, T.; FISCHETTI, M. Weaving the Web: the original design and ultimate destiny of the worldwide web by its inventor. New York: HarperBusiness. 2000.

BOLT J.; VAN ZANDEN J.L. The Maddison Project: Collaborative research on historical national accounts. The Economic History Review, 67(3): 627-651. 2014.

BOLT, J.; INKLAAR, R. JONG.H.; ZANDEN,J. L. Rebasing 'Maddison': New income comparisons and the shape of long-run economic development. GGDC Research Memorandum 174. University of Groningen, January 2018.

BULMER-THOMAS, V. The economic history of Latin America since independence. Cambridge: Cambridge University Press (Second Edition). 2003.

CENTENO, M. Blood and debt: War and the Nation-State in Latin America. The Pennsylvania University Press. 2002.

CEPAL and OECD. Latin American Economic Outlook 2019: Development in Transition, Latin American Economic Outlook Report. 230 pp. 2019. https://doi.org/10.1787/g2g9ff18-en.

CHIARINI, T.; CIMINI, F.; RAPINI, M ; SILVA, L. The political economy of innovation. Why is Brazil stuck in the technological ladder?. Brazilian Political Science Review, v. 14, p. 1-39, 2020.

COHEN, W.; LEVINTHAL, D. Innovation and Learning: the two faces of R\&D, The Economic Journal, v. 99, n. 397, September: pp. 569-596. 1989.

COHEN, W.; LEVINTHAL, D. Absorptive capacity: a new perspective on learning and innovation. Administrative Science Quarterly, v. 35, pp. 128-152. 1990.

COSTA, R. L.; VASCONCELOS, G. L., Long-range correlations and nonstationarity in the Brazilian stock market. Physica A, 329, 231-248. 2003.

DARWIN, J. The Empire project: the rise and fall of the British World-System, 1830-1970. Cambridge: Cambridge University Press. 2009.

DONER, R.; SCHNEIDER, B. Technical Education in the Middle Income Trap: Building Co- 
alitions for Skill Formation. The Journal of Development Studies. 56(8):1-18, April. 2019.

DUIT, A.; GALAZ, V. Governance and complexity-emerging issues for governance theory. Governance, v. 21, n. 3, p. 311-335, 2008.

ESCOSURA, L. P. The Economic Consequences of Independence in Latin America. In: BULMER-THOMAS, V.; COATSWORTH, J. H.; CONDE, R. C. The Cambridge Economic History of Latin America - volume I: The Colonial Era and the Short Nineteenth Century. Cambridge: Cambridge University Press, pp. 463-504. 2006.

FAGERBERG, J.; GODINHO, M. Innovation and catching-up. In: FAGERBERG, J.; MOWERY, D.; NELSON, R. (Eds.). The Oxford handbook of innovation. Oxford: Oxford University, p. 291-317, 2005.

FREEMAN, C. The National System of Innovation in historical perspective. Cambridge Journal of Economics, v. 19, n. 1, pp 5-24. 1995.

FURTADO, C. A economia latino-americana. São Paulo: Companhia Editora Nacional. 339 pp. 1976.

GOLDENFELD, N.; KADANOFF, L. Simple lessons from complexity. Science, v. 284, p. 87-89, 1999.

GOVINDAN, R. B., VJUSHIN , D., BRENNER, S., BUNDE, A., HAVLIN, S., SCHELLNHUBER, H. Long-range correlations and trends in global climate models: Comparison with real data, Physica A, 294, 239. 2001.

GUNDLACH, E. and PALDAM, M. A hump-shaped transitional growth path as a general pattern of long-run development, mimeo, 2019. available in: http://www.martin.paldam.dk/Papers/ GT-Main/11-Hump.pdf.

HARTWELL, C.A. Understanding "Development": Insights from Some Aspects of Complexity Theory. Homo Oecon. 34, 165-190. 2017.

HEIKKINEN, S. and NUMMELA, I. Economic Growth in Finland and in Sweden, 1733-2014 Comparative Estimates Paper presented at the Eleventh Conference of the European Historical Economics Society (EHES)University of Pisa, 4-5 September. 2015.

HENSEL, S. Was There an Age of Revolution in Latin America?: New Literature on Latin American Independence. Latin American Research Review, v. 38, n. 3, p. 237-249. 2003.

IVANOVA, K., AULOOS, M., Application of the detrended fluctuation analysis (DFA) method for describing cloud breaking. Physica A, 274, 349-354. 1999.

JONES, C.I. The Facts of Economic Growth, in: TAYLOR, J.B.; UHLIG, H. (eds) Handbook of Macroeconomics, Volume 2A. Elsevier. 2016.

KANG, N.; PAUS, E. (2020) The Political Economy of the Middle Income Trap: The Challenges of Advancing Innovation Capabilities in Latin America, Asia and Beyond, The Journal of Development Studies, 56:4, 651-656. 2020.

KHARAS, H.; GILL, I. (2020) Growth strategies to avoid the middle-income trap, Duke Global Working Paper 17, January 2020.

LIST, F. Sistema nacional de economia política. São Paulo: Abril Cultural. 1983.

MADDISON, A. The world economy: a millennial perspective. Paris: OECD. 2001.

MADDISON, A. The world economy: historical statistics. Paris: OECD. 2003. 
MADDISON, A. Historical statistics of the World Economy-1-2008 AD. Groningen Growth and Development Centre. 2010 (disponível em www.ggdc.net/maddison/Historical_Statistics/horizontal-file_02-2010.xls).

MALDONADO, C. History as an Increasingly Complex System, in: History and Cultural Identity. Retrieving the Past, Shaping the Future. HOGAN, J. (Ed.), Washington, D. C.: The Council for Research in Values and Philosophy, págs. 129-152. 2011.

MOREIRA, J. G., SILVA, J. K. L., KAMPHORST, S. O. On the fractal dimension of self-affine profile, Journal of Physics A, v.27, n.8097. 1994.

MYRDAL, G. (1957), Economic Theory and Underdeveloped Regions, Duckworth, London. 1957.

NELSON, R. R. A Theory of the Low Level Equilibrium Trap. American Economic Review, Vol. 46, No. 5., pp. 894-908. 1956.

NOVAIS, F. Portugal e Brasil na crise do antigo sistema colonial (1777-1808). São Paulo: Editora Hucitec, 1979.

NUSSENZVEIG, H. M (org.). Complexidade \& Caos. (editora UFRJ/Coppe. Universidade Federal do Rio de Janeiro.) 1999.

PAULA, J. A. Os limites da industrialização em Minas Gerais no Século XVIII. Revista Brasileira de Estudos Políticos, pp.63-104, 1984.

PAUS, E. Latin America and the middle income trap. Santiago: CEPAL. Series Financing for development. 56 pp. 2014.

PAUS, E. Escaping the Middle Income Trap: Innovate or Perish. ADBI Working Paper 685. Tokyo: Asian Development Bank Institute. 2017.

PEREZ, C. Technological Revolutions and Techno-economic paradigms. Cambridge Journal of Economics, Vol. 34, No.1, pp. 185-202. 2010.

Ribeiro, L. C., De DeUS, L. G., LOUReiro, P. M., AlbuQUerQue, E. M. Profits and Fractal Properties: notes on Marx, Countertendencies and Simulation Models. Review of Political Economy. pp 282-306. 2016.

RODRIGUES, L. A ciência pós-determinista, supradisciplinar e transparadigmática: reacendendo o debate sobre teoria, analogia e conceito. Trans/Form/Ação, 43(1), 151-172. Epub June 01, 2020.

ROSÉS, J. R.; WOLF, N. (Eds.) The Economic Development of Europe's Regions: A Quantitative History since 1900, Routledge, London, 2018.

ROTHMAN, A. Union, Capitalism and Slavery in the "Rising Empire" of the United States. In: TUTINO, J. (ed) New Countries: Capitalism, Revolutions, and Nations in the Americas, 17501870. Duke University Press. 2016.

SALES, J. A., MARTINS, M. L. , MOREIRA, J. G., One-dimensional cellular automata characterization by the roughness exponent. Physica A,. Volume 245, Issues 3-4, pp. 461-471. 1997.

SIMON, J. The ideology of creole revultion: Imperalism and Independence in American and Latin American Political Thought. Cambridge Unviersity Press. 2017.

SMELSER, N.; SWEDBERG, R. (eds) The handbook of economic sociology. Princeton/New York: Princeton University Press/Russel Sage Foundation (2 ${ }^{\text {nd }}$ edition). 2005. 
STEPAN, A. Federalism and Democracy: Beyond the U.S. Model. Journal of Democracy 10(4):19-34. 1999.

SUZIGAN, W. Indústria brasileira: origem e desenvolvimento. Nova Edição. São Paulo: Editora Hucitec/Editora da Unicamp. 2000.

TUTINO, J. New Countries: Capitalism, Revolutions, and Nations in the Americas, 1750-1870. Duke University Press. 2016.

WOO, E.T. The Key Obstacles to Success in Economic Catching Up by China, Reserve Bank Of Australia, Conference Volume 2016.PP.85-102. 2016.

WOOD, E. M. Empire of capital. London/New York: Verso. 2003.

ZHOU, M.; XIONG, W.; LI, X.; LIAO, H. The Middle-Income Trap and the Coping Strategies From Network-Based Perspectives. Entropy 20, no. 10: 803. 2018.

ŻUK, P.; SAVELIN, L. Real convergence in central, eastern and south-eastern Europe, European central Bank, Occasional Paper Series, No 212, July, 2018.

\author{
About the authors \\ Fernanda Cimini-fcimini@cedeplar.ufmg.br \\ Universidade Federal de Minas Gerais, Belo Horizonte, Minas Gerais, Brasil. \\ ORCID: https://orcid.org/0000-0003-2170-6443. \\ JorgeBritto - britto.jorge@gmail.com \\ Universidade Federal Fluminense, Rio de Janeiro, Rio de Janeiro, Brasil. \\ ORCID: https://orcid.org/0000-0003-0730-4958. \\ LeonardoCosta Ribeiro-lcr@cedeplar.ufmg.br \\ Universidade Federal de Minas Gerais, Belo Horizonte, Minas Gerais, Brasil. \\ ORCID: https://orcid.org/0000-0002-7772-9313.
}

\title{
About the article
}

Submission received on May 07, 2020. Approved for publication on October 10, 2020. 